\title{
Edwin L. Sabin, Literary Explorer of the West
}

\author{
PH I L P D. JORDA N
}

"Born, of course. We all have to start out that way. I was born in Rockford, Illinois. I did not choose the date. It was so near Christmas that my birthday presents served as Christmas presents. I should not advise anybody to be born at Christmas time."1

That's the way waggish Edwin Legrand Sabin, Iowa author of adventure books for boys and of histories of the trans-Missouri West, introduced himself to scores of his readers in 1911, when he was age forty. It is true that Sabin was born in Rockford on December 23, 1870, that he came from colonial and Yankee stock, and that his father moved from Rockford to Clinton, Iowa, before the lad was a year old. There Henry Sabin became superintendent of schools. In young Sabin's nostalgic memory, Clinton was an ideal place for a youngster to grow up, for it was a Mississippi River community. In that "old-time river town" Sabin remembered "steamboats, sawmills, log rafts, fishing, hunting, swimming, camping, and I was brought up with Tom Sawyers and Huckleberry Finns." His father schooled him in the ways of the neighboring woods and the great river. Again and again Sabin wrote that he first learned to love the out-of-doors in Iowa and particularly in the environs of Clinton, which he gleefully claimed was situated upon the St. Anthony's Nose of the state.

Sabin's formal education, sometimes taught to the tune of a hickory stick, was received in the city's grade and secondary schools. After graduation from the Clinton High School in 1888, he moved inland to spend four years as an undergraduate at The University of Iowa. Although an active, enthusiastic member of Beta Theta Pi, he did not

I Unless otherwise indicated, all material used in this article is from Sabin material in the Iowa Authors Collection, the University of Iowa Libraries. Copies of the Sabin-Ghent correspondence, included in the collection, were furnished by the Library of Congress. The author is indebted to Mr. Robert A. McCown, of the Special Collections Department, for making the Sabin manuscripts, papers, letters, books, and memorabilia available and for sharing the results of his own research. Had it not been for him, this article could not have taken the form it has. 
permit fraternity life to interfere with academic duties. It is unfortunate that his scholastic record was destroyed by fire, so that both the classroom assignments he undertook and the records kept by his professors are unavailable, but he certainly was a superior student, for he was graduated with Phi Beta Kappa honors. As an undergraduate Sabin read widely and was bitten by a desire to write and publish.

Just what he wanted to write at age twenty-two, when he left Iowa City with his sheepskin diploma, is uncertain. Perhaps he thought of himself as a budding poet or a master of the short story or even a distinguished novelist. Sabin kept his dreams well concealed. He was realistic enough to realize that the path of least resistance, one which would support him and give him writing experience, was newspaper reporting. For the next few years Sabin covered local news for papers in Iowa and Illinois, including the Daily Herald in Clinton, the Daily News and Daily State Register in Des Moines, and the Morning Democrat in Davenport. He spent some time on the copy desk of two Mllinois journals, the Peoria Herald and Chicago's Campbell's Weekly.

In October, 1892, when Sabin was telegraph editor of the Des Moines Daily Capital, he heard that The University of Iowa was planning an expedition to the Bahama Islands. $\mathrm{He}$ immediately scrawled off a letter to C. A. Schaeffer, the University's president, asking that he be attached to the exploring party as a special correspondent, "for I could produce a very interesting account of the doings; and could aid the University materially in the columns of the press."

To Sabin's amazement, his wish was granted. In May, 1893, he joined Professor Charles C. Nutting's party of fourteen men and seven women for the long, adventuresome trip from Iowa City to tropical towns and lovely islands which were to fascinate a young man grown up in the midst of tall corn and stands of waving wheat. Nutting, professor of zoology and curator of the University's natural history museum, ordered the captain of the Emily E. Johnson, a fruit vessel, to put in at Egg Island, to drop anchor at Havana, to stop at Bird Key, to visit the Dry Tortugas and Spanish Wells, the latter a typical settlement of the British West Indies. At each stop Sabin saw Nutting's students collect varieties of sea life-crustaceans, sea fans, conches, and "the very finest biological material of almost endless variety." The party swam in blue waters which lapped beautiful beaches of white sand. Now and again, members trudged inland, laden with cameras, bug nets, and machetes. They hacked their way through tough thickets in search of specimens. ${ }^{2}$

2 For an unsigned account of the expedition, see Class of '95, The Hawkeye (Iowa City: State University of Iowa, 1894), pp. 13-32. 
Possibly the naturalists, despite seasickness and bites and scratches, relished the voyage's activities more than Sabin did. How many stories he wrote and filed and how many were published is uncertain. An unsigned dispatch, probably written by Sabin, was printed in Iowa City's The Iowa Citizen on June 30, 1893. Its first sentence strikes a sour note: "Our trip is a little more than half over, and I hardly think there is much regret on the part of most members of the expedition." Then the mood changes. The author comments enthusiastically upon a humorous episode in Havana, where expedition members attempted to locate the burial place of Columbus. There is mention of "strange and beautiful" vegetation and of great waves breaking at one's feet and of attempting to realize what the breakers had been doing through all the centuries. One could look through water clear as glass and see "waving plant-like forms of growing coral, crabs, fishes, long spined and dangerous looking sea urchins, beautiful anemonies-some of them growing like colonies and carpeting the sea like a moss-and a thousand and one other curious and interesting things."

When the expedition returned to the United States in July, 1893, Sabin resumed his newspapering. While working in Chicago in 1896 he met and courted Mary Caroline Nash, an Iowa girl nine years younger. They were married on October 7 . Some four years later, feeling that "work on the city staff of a daily paper is good training for a writer," Sabin began composing verse and prose for publication in nationally known magazines. This decision to forsake regular employment with a steady income for the precarious life of an author was a hazardous gamble. Yet it was to lift Sabin for a few decades into the top rank of American authors of both fiction and non-fiction and then, for reasons which he never really understood, send him skidding into the land of has-beens, where he died in abject poverty. In a way, Sabin's career was an Horatio Alger story in reverse.

Manuscripts poured from his pen. He published in the best and most popular magazines-The Chautauquan, St. Nicholas, Country Life, Everybody's Magazine and, among others, McBride's Magazine. A favorite theme for verse was Christmas. He wrote of the return of Santa Claus, related the adventures of the littlest boy and Santa Claus, and entitled one of his pieces "Just Before 'Chris'mus." He told the Easter story. Apparently Sabin tried his hand at any subject which came to mind. He wrote of the "bad boy" for the Saturday Evening Post. Outing Magazine published his story of a plucky white man, a hunter who ranged the plains with a Sharpe's rifle to kill buffalo. Little by little his attention turned to the West. One of his pieces, published in Everybody's Magazine in 1906, described the frontier out- 
law. Somehow or other he got hold of the experiences of a southern merchant in business near Vicksburg, Mississippi, during the $1860 \mathrm{~s}$. Sabin "arranged" the narrative and saw it appear in The Sewanee Review in October, 1907.

While peppering top-quality magazines with poems and articles, Sabin made his first attempts at writing children's books. His fumbling The Magic Mashie and Other Golfish Stories, published by A. Wessels in New York in 1902, even though it concerned a game recently introduced into the United States, was of more interest to adults than to children. The book failed to bring him the recognition for which he yearned. When he tried again in 1905 with The Beaufort Chums, the results were much the same. There was, however, one significant difference. The tale of the Beaufort boys was published by T. Y. Crowell, an old-line, distinguished company. Crowell editors apparently sensed promise in Sabin, for they urged him to submit more manuscripts. Thus began an author-publisher relationship which was to continue for years.

It is possible, although the evidence is not conclusive, that Crowell helped turn Sabin's talents to writing about the frontier West, an area in which he had already shown interest, for he had published about the buffalo hunter, the outlaw, the coyote, and the great range country. The dime novel was captivating multitudes of readers. Books such as Andy Adams' The Log of A Cowboy, first published in 1903, were avidly read. Buffalo Bill's Wild West Show was an established institution. The West, in short, was a living legend, and it was about time for a knowledgeable and readable author of boys' books to cash in on the trend.

Unlike writers of dime novels who turned out scores of western thrillers while residing in New York City and never venturing across the Hudson River, Sabin decided to move west, first to tarry briefly in Denver, and in 1911 to follow the trail leading to San Diego, California. Two years later the Sabins established themselves in La Jolla, an attractive small town built on a rocky promontory overlooking the sea. There, with the exception of vacations and research trips, they remained for eighteen years.

The years from 1913 to 1931 were the fruitful ones-the time when Sabin perfected his craft, when he developed skills and intuitions, when he learned some research techniques, and when one book followed another. He possessed the eye of a scientist, the patience of a research historian, and the flair of a romantic novelist. The more he learned of the West and its history, the more he loved it and wrote about it: 
Oh, Western land, oh, Western land,

Of bounding blood, and red;

By peak and vale on leads thy trail

For those of fearless tread.

And he who shall elsewhere take his way

That once thy trail has pressed,

Must ever yearn, and dream return,

To thee, oh, magic West.

While busily expanding his knowledge of Spanish trails and mission churches and while watching the dance of the tumbleweed and seeing Indians weaving intricate baskets, Sabin realized that he must learn more of the nation's heritage. Something lay behind the march of the Mormons, behind the discovery of California gold, behind the Mexican and Civil wars. He began to understand that the trans-Missouri West was only one of many and varied frontiers. He admitted that he knew little of the French-Canadian regime with its royal governors and sturdy fur trappers and colorful voyageurs. He was unacquainted with the history of colonial New England and the Middle Colonies. He was only dimly aware of the Ohio country and the spread of settlement across the Mississippi. The Old South did not seem to attract him, then or later.

He set to work filling the gaps in his knowledge. He read omnivorously, purchasing books and borrowing others from libraries. One day he came upon a primary principle: history, whether national or sectional, was largely a narrative of conflict. If, Sabin thought, history was an adventurous confrontation between free men and serfs, between the true and the untrue, between good and evil, and between heroes and villains, then he always would march with those who battled for righteousness.

He made this point in practically every book he wrote for boys. So did his publishers. For example, the jacket blurb of Bar B Boys or The Young Cow-Punchers, published by Thomas Y. Crowell, stated that the story stood for high ideals and courage of the right sort. The publisher added that "stories like this are valuable in treasuring for us this phase of passing American life and manners." On the dedication page of Gold! A Tale of Great and Romantic Adventurings by Argonauts upon Land and Sea in That Eternal Quest of the Golden Fleece Which Lured Captains and Companies into the DragonGuarded Unknown and Altered the Face of This Western Continent, Sabin moralized: "Take Heed! Gold by itself is only inert yellow metal, but by human touch it is vitalized to be a blessing or a curse." 
In his Wild Men of the Wild West, Sabin commented: "All in all there is little romance in man killing man. At the best it is a grim business and a poor business. And to depend upon the gun likewise is a poor business." The volume carried lively accounts of the nefarious activities of, among others, Mike Fink, Henry Plummer, Wild Bill Hickok, Billy the Kid, and Calamity Jane.

Whether Sabin was contributing to the "Trail Blazer" series, published by J. B. Lippincott, or to the "Great West" and the "Range and Trail" series, issued by Crowell, his plots were ingenious and his research as meticulous as he could make it. He soon learned that historical investigation was much like stepping into quicksand-the more one struggled to find truth, the more one sank by the pull of endless problems and queries. He did the best he could, scouring the country for primary sources and hard evidence. Perhaps no author of juveniles of the day labored harder to base his work on facts, or what were believed to be facts.

Sabin's Wild Men of the Wild West rested in part upon the Draper manuscripts in the State Historical Society of Wisconsin; upon documentary sources in the Mississippi State Department of Archives and History; upon materials in the collections of the Kansas State Historical Society; upon first-hand accounts in the public and state libraries of Kentucky and Iowa; and upon printed classics, such as Hubert E. Collins' Warpath and Cattle Trail and Zoe A. Tilgman's Outlaw Days.

For his spirited On the Plains with Custer, published by Lippincott in 1913, Sabin went out of his way to inform readers that he had used Custer's own story-“It lies before me." In addition he used books by Mrs. Custer, Captain Whittaker's biography of Custer, Randolph Keim's book, "and magazines and pamphlets of time agone." He did much the same in With Carson and Fremont, proudly pointing out that he rooted the narrative in the journals of exploring expeditions commanded by Fremont and advised by Kit Carson "as transmitted by the Secretary of War to the Senate and House and published as government documents." Sabin emphasized that Oliver Wiggins, one of his characters, "is real." Sabin said he had talked with Wiggins and "He was the little boy under the wagon, and he was the Taos lad who won the Kit Carson rifle; he was upon the Fremont and Carson First Expedition, and he was upon the Second Expedition by way of the Salt Lake to Fort Hall."

In his Lost with Lieutenant Pike, a Lippincott book of 1919, there is no doubt that Sabin, as he said, leaned heavily upon and drew much from Zebulon M. Pike's An Account of Expeditions to the Sources of the Mississippi and Through the Western Parts of Louisiana. The photograph of Pike was taken from the 1810 edition of the Expedi- 
tions; the description of a fort is an accurate paraphrase of Pike's description in his journal for February 6, 1807; and Sabin's account of Pike's reading French is from the entry of February 8, 1807. What Sabin really did in this book was to take Pike's diary and use it as a base and major source for a juvenile. Interestingly enough, Sabin ignored the fact that Pike was connected with the Wilkinson-Burr scheme for empire in the Southwest.

Now and again, especially during the later years when income decreased and he felt obliged to hurry, Sabin, as he had earlier in the Pike volume, relied upon general knowledge plus a single source. Thus it was in 1941 when Lippincott published Pirate Waters: A Story of the Old Navy. In 1855, Henry Augustus Wise, then a naval officer writing under the pseudonym of Harry Gringo, penned an exciting, intimate account of life at sea. Sabin came upon a copy of Wise's Tales for the Marines, took what grist he could use, and turned it into a book of his own. But more frequently he sowed and tilled before he harvested or before he plundered another's field. His Building the Pacific Railway, a non-fiction account published by Lippincott in 1919, resulted from arduous digging. Sabin searched files of old newspapers; corresponded with J. H. Strowbridge, railroad superintendent of construction; interviewed Robert B. Moore, a blacksmith who helped drive the golden spike; was in touch with General Grenville M. Dodge, chief engineer of the Union Pacific; and fought his way through government reports, railroad records, and guidebooks. Even today the book is well worth reading, although recent studies have revised both details and interpretations.

In addition to haunting libraries and pestering archival staffs with queries, Sabin maintained a steady and persistent correspondence with all types of persons who might hold information which would throw light upon historical incidents and increase accuracy and verisimilitude. He wrote Major Jerome W. Howe, editor of the Cavalry Journal, in 1923, expressing appreciation for a copy of Trumpeter Martin's narrative of the Little Big Horn catastrophe, telling Howe that "the Custer campaigns have been studied again and again by me." A stream of letters passed between Sabin and William J. Ghent, author of the Road to Oregon, contributor to the Dictionary of American Biography, and an avid historical sleuth. In a letter dated September 3, 1933, Sabin told Ghent he thought Major Marcus A. Reno was "a lusher and had other practices," and that in Sabin's opinion the entire story of Custer would never be set down by an army pen, "for neither the army nor the navy will wash its dirty linen in public."

Sabin typed letters on an old machine which, he said, "deserves to be turned out to pasture." His correspondence is readable. Unfortu- 
nately, Ghent scrawled replies in appalling longhand. He seldom dated them fully, sometimes neglected to sign them, and procrastinated in replying. Sabin wrote specifically and to the point. Ghent was vague and diffuse. Ghent wrote more of relations with publishers. Sabin, although vitally concerned with contracts, devoted more space to research puzzlers. Sabin's letters were marked by frankness, Ghent's by a certain condescension. Yet Ghent gave Sabin excellent advice concerning relations with publishers and also passed along trade news and gossip.

The Sabin-Ghent correspondence demonstrates that Sabin, although he researched as best he could, was aware that some of his books were -at least in places-less than accurate. He had no doubt, he wrote in May, 1929, that his Wild Men of the Wild West was full of errors. He spoke of Klondike Pardners, published by Lippincott in 1929, as the "usual fictionized stuff" for boys. He characterized "Old" Jim Bridger, issued by Crowell in 1928, not as a biography but as a running yarn bunching together Bridger's adventures, explaining that "the chronology is not all in line for I had to combine dates in order to maintain action." Sabin was motivated by a desire to collect all he could upon a subject and, after gathering material, to reconcile conflicting evidence; but the smashing impact of the developing national economic distress which exploded in 1929 compelled him to cut corners. In short, he was obliged to write rapidly in order to support himself.

Yet Sabin cast research nets as far as his strength and his finances would permit. He regretted that he was not within reach of the $\mathrm{Li}$ brary of Congress and he implored Ghent, who resided in the nation's capital, to send him addresses of second-hand bookshops where he might pick up copies of old public documents and volumes of the Congressional Globe. He rejoiced when he was permitted to work in the Bancroft Library. He scouted for family letters and memoirs and was delighted when he discovered in Santa $\mathrm{Fe}$ documents belonging to General Eugene A. Carr's family. Carr, who fought Indians before the Civil War, returned to frontier combat after the peace, leading forces against the Cheyenne, Sioux, and Apache.

Once Sabin spent a dollar for a copy of Herbert Cody Blake's Blake's Western Stories. The book, he acknowledged, was well worth the price, for, according to Blake and various old stagecoach drivers and guards, "Cody never killed an Indian, and Hickok could not shoot." Sabin interviewed a La Jolla acquaintance who had been an enlisted man "in the infantry detachment that went into garrison at Abe Lincoln" when the Seventh Cavalry rode out. Fort Abraham Lincoln, originally named Fort McKeen, was situated not far from the present site of Mandan, North Dakota. As a result of his interview, Sabin learned 
that Custer was a thoroughly hated, high-headed, high-handed, mean man. One need only glance through the appendices and notes of Sabin's two-volume Kit Carson Days, published by The Press of the Pioneers in 1935, to comprehend the author's valiant attempts to secure sources.

How Sabin managed to track down so many individuals closely connected with events and persons about whom he was writing is difficult to determine. Probably, like any historian-detective, he doggedly followed a succession of clues until he found his man. Two examples must suffice. One day in 1926 Sabin began an extensive hunt for information about California Joe, Custer's valued scout. Somehow Sabin located in Berkeley, California, a Dr. Valentine T. McGillycuddy, who had served with both Custer and California Joe in the Black Hills exploring expedition of $\mathbf{1 8 7 5}$. Sabin quickly mailed a letter to the Hotel Claremont, where the ex-military surgeon resided. He was rewarded with a prompt reply and with information which thrilled him. Yes, McGillycuddy remembered California Joe well and considered him most competent and reliable. California Joe had "an intuitive knowledge of country, over regions he had never visited." In the autumn of 1876, the doctor continued, some months after the tragedy at the Little Big Horn, troops, including McGillycuddy and California Joe, reached Fort Robinson, Nebraska. There California Joe met an old enemy. The year before, California Joe and Tom Newcomb, the post butcher, had quarreled over the murder of a French squaw man.

The feud broke out again in the Post Trader's Bar on October 29, soon after McGillycuddy and California Joe arrived at Fort Robinson. Newcomb threatened to shoot the scout, but California Joe called out, "Drop your gun, Tom, line up here and take a drink." Newcomb did, and the crisis passed. About an hour later McGillycuddy heard a shot near the corral. When he arrived, he told Sabin, he found "Joe on his face dead, a Winchester ball having ploughed through his chest from the rear." Newcomb was arrested and confined in the guardhouse. When McGillycuddy removed California Joe's clothes preparatory to autopsy, he found papers proving that the scout's real name was Moses Embree Milner, that he was born near Stanford, Kentucky, that he journeyed to California during the gold rush, and from there roamed the West as miner and scout. He was buried in the post cemetery. A red cedar headboard marked the grave. All this was exactly the information for which Sabin was searching. ${ }^{3}$

3 Descriptions of California Joe may be found in General George A. Custer. My Life on the Plains, edited with an introduction by Milo M. Quaife (Lincoln: University of Nebraska Press, 1968), pp. 234-38; also, Joe E. Milner and Earle R. Forrest, California Joe (Caldwell, Idaho: The Caxton Printers, 1935). 
During the spring of 1929 Sabin attempted without success to gather personal details of Calamity Jane's checkered career. Finally, on June 13, 1929, he learned that S. G. Tillett, of Alliance, Nebraska, might provide information. Sabin immediately wrote him. Tillett replied quickly. A former railroad man, he readily and easily recalled the circumstances surrounding Calamity Jane's last days-the very facts which Sabin needed for background in his sketch of her for Wild Men of the Wild West. To paraphrase Tillett's account would destroy a flavorful sense of immediacy.

About July 15, 1903, Tillett said, he was standing on the siding at Englewood, South Dakota, awaiting the arrival of the southbound passenger train from Deadwood:

It came in on the opoasite track and stood beside the Eng I was running and I saw Calamity in one of the coaches and ask her whare she was going, and her reply was I am making the rounds of the hill towns for the last time and am going to cash in, she was bound for Hot Springs, and went from thare to Buffalo Gap Rappid City Sturgis White Wood Bell Fourch, And about the Latter part of July Showed up at Spearfish, and on the Morning of Aug 3rd came to the traine just before leaving time, I had quite A long conversation with her In which she againe informed me she would not live long and said she was ready to go, we put her on the traine and when we arived at Terry S.D. I ask the Conductor if she was not getting off thare, he informed me he was not sure. . . . While the crew were unloading the Freight I went to the Coach and Awakened her she was verry weak from disipation and drink and lack of nurishment, as she had been drinking verry heavily while in Spearfish and had not eaten much. She stoped with Jack Kingsley who was a Saloon Keeper thaer and had known her since coming to the Hills in 76. and had a verry kindly feeling for her. After I got her onn her feat she seemed to take new life but i was compeled to carry her from the tratn and asisted her to the trail that led down the hill to the town she tyrned and Thanked me and said good by Kid and that was the last time I saw her alive as she died before we left Deadwood ao our return trip tp Spearfish the time was about 1 P. M. I think. She was both drunk and sick and I will alwas remwmber she was verry frail and was A bundle of rags and filth, but was loved by manny of the old timer who gave her the best burial the town could aford, and had the largest funeral I had ever sean in Deadwood. I have wondered what interest you had in our old friend Calamity, let me here from tou againe I am curious. 
Tillett's letter, although helpful, did not tell Sabin that Calamity Jane, born Martha Jane Cannary, was buried close to the grave of Wild Bill Hickok or that she began her western career as a post prostitute at Fort Laramie, Wyoming. ${ }^{4}$ Sabin learned those details from other sources. The more he attempted to ferret out accurate details of those who broke the law and those who kept it, the deeper he sank into quicksands of legend and myth. Ben Williams, deputy United States marshal, and William M. Tilghman, who involved himself with Wyatt Earp, sent Sabin on such an irritating search that he confided to Ghent, "I fully agree with you upon the exasperating difficulty of obtaining accurate data upon the careers of Wild Bills and other frontier 'heroes.' From deeds to dates everything is in confusion and a state of prejudice."

When he wrote that in May, 1929, Sabin was relatively well off in his La Jolla residence, living modestly but comfortably. He was considering purchasing plates of a few of his books from publishers and selling them for the printing of new editions. All this changed on Black Friday in October, when the stock market crashed as a prelude to a national depression. By November, 1930, Sabin's spirits seemed to have fallen as low as blue-chip stocks. He was not finding source material he needed. "The work of a research historian," he moaned, "seems easy to a lot of gifted fellows, and they just jump in and throw facts around and call it a day." During the spring of the following year he admitted for the first time that he was hurting from lack of money. "I don't know of anybody in my acquaintanceship," he wrote, "who has not suffered a set-back of one kind or another. The stars have been adverse."

No longer could he spare the time to work on book-length manuscripts, for he had to get "quicker action, with short stuff, and that market is badly shot, also." In late 1931 or early the next year, the increasing economic crunch forced the Sabins to give up their residence in La Jolla and move inland to Hemet. Situated in the heart of the Indian country, Hemet lay some sixteen miles from Perris, an old goldmining town. There, in order to make ends meet, Sabin began what he termed a "criticism sideline."

By October, 1932, Sabin was mailing flyers, printed on pale green paper, to aspiring authors in need of critical advice and editorial help and assistance. He promised constructive, thorough, businesslike, but

4 Herbert S. Schell, History of South Dakota (Lincoln: University of Nebraska Press, 1968), disposes on page 150 of both Hickok and Jane with a single sentence: "Moreover, characters of such dubious repute as Wild Bill Hickok and Calamity Jane have been transformed into legends." See also Dale T. Schoenberger, The Cunfighters (Caldwell, Idaho: The Caxton Printers, 1968), pp. 86, 88, 90. 
friendly and personal cooperation in the preparing and placing of short stories, articles, and longer manuscripts for a fee of only ten dollars. "If," stated his circulars, "you have writing talents to be developed or writing problems in hand, lay them before a writer and critic who is . . . experienced in a wide field, who as an Eastern editor recently said, 'seems to know what story writing is all about.'" The project failed. Sabin admitted that the trouble was that prospective clients had little money. In addition, competition was fierce. Established critics as well as racketeers were offering the same service. "I can meet the former," said Sabin, "but the latter have me buffaloed."

Nevertheless he persisted. Desperation, rather than business sense, drove Sabin, after failing in his first venture, to write and publish what was virtually a correspondence course in writing. Somehow or other he managed in 1932 to persuade Authors Associated in Minneapolis, Minnesota, to print eight pamphlets for use by aspiring authors. Perhaps Sabin himself was Authors Associated and perhaps he paid for printing the pamphlets, but nothing in the Sabin Collection confirms or refutes this. He did, however, write all the copy for the manuals. The first was entitled You, Too, Can Write Short Stories!

Calling himself a professional coach, Sabin told students that he would teach them to write a good story by "writing one with you," and that he would instruct in such a manner that "your later stories, written alone, will win serious editorial consideration from the man who deals out the checks." This was the cheapest sort of popular appealing, which Sabin must have recognized for what it was. The scope of the lessons ranged from discussions of characters, characterization, and dialogue, through plot construction, story titles, and beginning a story, to the story body, and how to end a story. The series concluded with a laboratory tale, "The Man Who Wasn't Licked," which Sabin wrote and analyzed sentence by sentence and dissected paragraph by paragraph. From all available evidence, the venture was stillborn.

For seven years the Sabins sweated out the Depression and its aftermath in Hemet. Then they returned to La Jolla, but not to their former residence, for three discouraging years. In 1941, realizing but not admitting that he had reached and passed his productive peak, Sabin went back to Hemet, where he and his wife remained the rest of their lives. When his spirits were low, Sabin comforted himself by recalling that his "Trail Blazers" series had been endorsed by the librarian of the Boy Scouts of America and that the Journal of Education once said he wrote books for boys in a way that fascinates every boy. Reviews had been generally favorable, and his books were treated kindly in journals such as The New York Times, Review of Reviews, the Times 
Literary Supplement, and the Nation. J. Frank Dobie spoke of the Carson volume as "A work long standard, rich in rendezvous, bears, and many other assorted topics." Bernard De Voto wrote Sabin in September, 1943, saying, "I have known and used your work for many years, have leaned upon it heavily, as you doubtless realize, and am now having the pleasure of starting a young son through your books."

Gratifying as such praise was, Sabin confessed to Ghent that he must turn to potboilers for a living until times loosened up a little. His Carson book proved a financial loss. Sabin said he never would get back the time he spent upon it. Now and again during the 1940s, he managed to place an editorial or a book review in periodicals such as The Saturday Review of Literature. His net income in 1941 amounted to $\$ 675.14$. His total royalties from Lippincott for 1943 came to only $\$ 113.13$, and the amount covered sales of eleven titles, including $O n$ the Plains with Custer, In the Ranks of Old Hickory, and Opening the West with Lewis and Clark. Apparently, in an effort to increase income, Sabin published a few stories under the names of W. H. Asper and Yoric Scott.

To bolster his courage during the lean years when he was in his seventies, Sabin wrote little jottings to himself: "If you can write, and knowing that, no judgment is better than your own." He noted that neatness and directness of expression were desirable. Yet his own manuscripts were not always neat. When, in 1951, he submitted a story to a New York literary agent, it was returned promptly with the terse notation that it was too short and the copy too difficult to read. How different that was from an earlier period when Sabin received a thousand dollars as first prize for his "The Song of Roland," published in Outdoor Recreation for November, 1922. The agent's curt reaction was matched in November, 1946, by a Crowell editor. She had returned a manuscript entitled This Land of Ours, saying, "Unfortunately, we feel the material is too crammed with facts and too artificial to warrant its publication."

Sabin's mental distress was somewhat relieved by two unexpected recognitions. He was listed in Who's Who in America, which pleased him immensely. In May, 1947, The University of Iowa notified him that he had been named to receive an Iowa Alumni Certificate of Accomplishment at the coming June commencement. He longed to return to Iowa, but his finances were meager. Furthermore, his wife was ill. He wrote President Virgil M. Hancher that he could not attend, adding, "This special attention from the University I consider not only a high honor but a very gracious action." His certificate and copies of the commencement program were mailed to him. 
Two years later The University of Iowa again approached him. This time Miss Grace Van Wormer, assistant director of the library, invited Sabin to donate his manuscripts. Sabin replied by saying he was trying "to turn up something," but that "Whenever a manuscript has gone into print I destroy whatever copy I may have at my end." He wrote again in July, 1952, saying he still was searching for papers and copies of his books. "I have always considered myself an Iowan," he said, "for tho' born in Illinois I was transferred to lowa when eight months old, was raised and educated in Iowa, married an Iowa girl, started ny magazine and book work there, and have been honored by the University. My roots are in Iowa." A few days later he mailed three photographs of himself, but no books or papers.

Perhaps Sabin was too occupied with a battle for survival to do more than struggle to keep body and soul together. He had plummeted from peak to pit, and he knew that escape was impossible. His health began to fail in 1947, and he sought out a physician who prescribed herbal remedies. The poisoning of his dog, a beautiful setter, ran up veterinary bills. Sabin's wife died, at age seventy-eight, on September 27, 1950. A year later Sabin was accepting aid from the Hemet Department of Public Welfare. He broke his hip in February. 1952, and was hospitalized.

Despite all misfortunes Sabin sporadically attempted to claw his way upwards. For some years he had enjoyed a lively correspondence with Henry James O'Brien Bedford-Jones, a prolific author of western stories and more than a hundred novels. The death of this pen pal in 1949 was another blow, for Bedford-Jones bolstered Sabin's sagging spirit with all sorts of suggestions and ideas for articles and yarns. He told Sabin to

Roll your own, last stand stuff. Lost wagon from a train. Prospectors. The old hokum of a generation past; time for the wheel to turn over now \& bring it up. . . . I'd say lay off history, use imagination. A run-in with Sitting Bull on his way to Canada; an adventure with Chief Joseph, another with Geronimo-what the hell! If you can spread in the appealing character that gets the reader's sympathy from the start ... go to itl Lay off the quivering heart and trembling lips-nobody loves that. Try a missionary, a train-robber on the lam, anything. Good present-day story is the old boy who's robbed everything from stage coach to autobus, \& now wants to die happy after robbing an airplane-and does, thanks to luck. Or thinks he does.

Once Bedford-Jones suggested that Sabin return to writing "all the 
old hokum from Buffalo Bill \& Diamond Dick days." He shot ideas as rapidly as bullets from a Gatling gun: "Man stumbles on a dead man, his partner stumbles on a sack of gold, and they fight it out-simplest equation. Must be dramatic. Woman won't hurt, of course, if you can make her unlike your standard halfbreed character." He suggested that Sabin try a different part of the world as background for each new story. Curiously enough, Bedford-Jones came up with the suggestion that Sabin wrap a yarn about a lost Missouri River steamboat laden with whiskey. He was referring, of course, to the ill-fated Bertrand, which sank in 1865 and was discovered and excavated in 1968-69, an event resulting in national publicity. ${ }^{5}$

"Dear Sabe," however, rebelled at Bedford-Jones" proposals and rejected them. Never, throughout his long career, had he based stories exclusively on bunkum and sheer imagination. He had, now and again, come close, but he had never reached the point his friend recommended. Sabin cherished the belief that he was an historian, or at least followed methods of the researcher. Only after root materials were in hand and digested did he package them in fictional form. Frequently, in both fiction and non-fiction, Sabin provided readers with chronologies to which they might refer. His Gold Seekers of ' 49 was prefaced with a timetable. He aimed to instruct as well as entertain.

Sabin would have been both ashamed and mortified if any of his major works had carried the statement that characters, places, and situations were imaginary and bore no relation to any person, location, or actual happening. He was satisfied only with "the real thing," or at least as genuine as he could make it. He was not above using the tricks of the writing trade, but he was adamant that substance be accurate. He studied hard to achieve his goal. He learned Spanish, so that his Mexican characters spoke correctly. He knew countless details of ranching, sheep herding, gold mining, and the cowboys' frontier. $\mathrm{He}$ acquainted himself with the details of army uniforms, and could write of guns, wagons, harness, and horses as if he had been raised in the service. His geographical references and backgrounds normally were correct. He learned the tricks by which settlers evaded the Homestead Act. In Scarface Ranch, or The Young Homesteaders, a character explained that "Molly has five acres and I have five acres, and we built this cabin right on the line, so she lives on her side and I live on my side, and the kitchen is in the middle. The line runs straight through the stove."

5 For a complete account, see Jerome E. Petsche, The Steamboat Bertrand: History, Excavation, and Architecture (Washington: Government Printing Office, 1974). 
Into his books went portions of tall tales, references to "seeing the elephant," and comments upon slavery, Negro labor, the Missouri Compromise, and the dramatic opening of the Oregon country. $\mathrm{He}$ talked in Rio Bravo of a "sallow, sharp-faced, beak-nosed, devil-maycare man, with ragged tobacco-stained moustache, a sly cast of one pale eye, and high shoulders carried jauntily as if to deny his gaunt apparel." Describing the hands of a gambler, Sabin wrote:

All that the lieutenant could see was a pair of hands, and of wrists cut by black sleeves fringed with snowy wristbands, and yet the sight fascinated. They were white, thin hands, agile in movements, cold in repose, and busied with cards or with money. Sometimes they shuffled the deck, and their precision in this case was remarkable. They dealt, and the cards fell clack, clack with the regularity of tick-tock.

Perhaps, as he lay in his hospital bed, Sabin recalled how years earlier he had labored over writing a satisfactory picture of Custer: "His skin was fair, with just a touch of sun-brown; a long blonde mustache drooped along either side of a firm clean chin; his nose was a bold hawk nose, and as piercing as the eyes of a hawk were his eyes of steely blue." Sabin had hoped that boys would be thrilled when they read of the General's pair of ivory-handled revolvers, shiny flexible boots, white doeskin riding breeches, and blue flannel shirt trimmed down the front with red. Perhaps Sabin's memory jerked back to Andy Jackson Craig, his hero of In the Ranks of Old Hickory. How Sabin labored over creating Andy! He was a bareheaded boy with tousled red hair. Dressed in cotton shirt, deerhide leggins and deerhide moccasins, Andy carried a powderhorn and a bullet pouch and reined his pony with a rope bridle.

The sick man had lost that extraordinary ability to put smells and sounds upon paper. He once made his readers hear the crumpling of a sage leaf between thumb and forefinger. He wrote so graphically that pungent smoke from campfires almost smarted in the eyes. Coffee, bubbling in a tin pot, stirred a craving. The wind, indeed, did howl. One could listen to popular songs, feel the searing pain when arrows struck, smell buffalo dung, hear spikers and bolters at work laying railroad track, and even see the morning unfolding of prairie wild flowers. Eardrums hurt when Sabin's war drums beat.

Just when Sabin stopped sketching ideas for plots, ceased jotting down historical facts fetched by bits and pieces from the lumber attic of his memory, gave up shuffling and sorting notes, and fed the 
final sheets into his ancient Barr typewriter cannot be precisely dated. Probably he ended all serious attempts at creative writing shortly after his wife's death. Eighty years old in 1950, he sensed that stars were looking down upon him with ten thousand eyes. Early in November, 1952, he again broke a hip and again was hospitalized. He died, a ward of the county, on November 24. His ashes were buried next to those of his wife in Evergreen Cemetery, Riverside, California. 


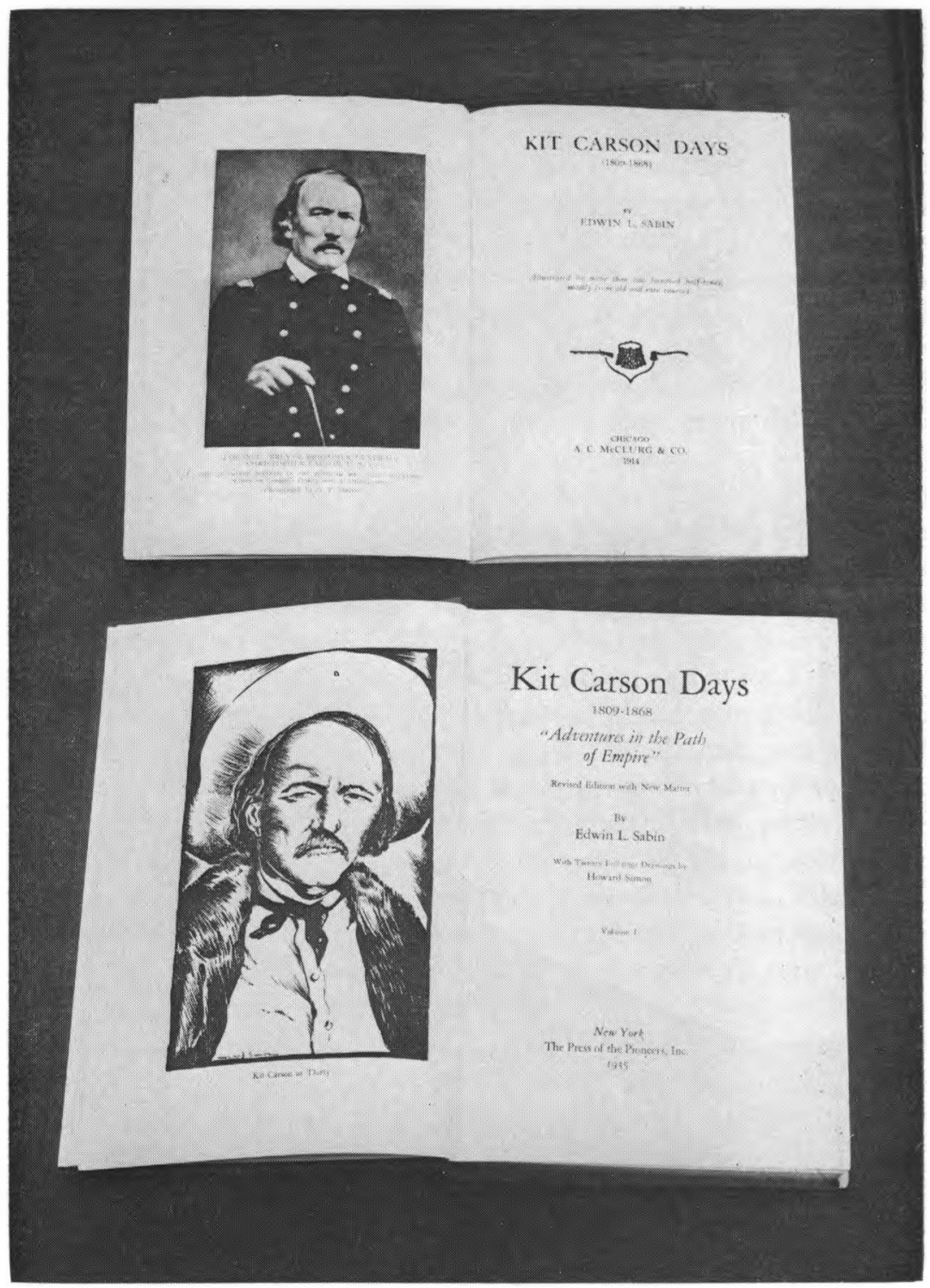

Kit Carson Days is probably the best-known book by Edwin L. Sabin. The first edition, shown at top, was published in one volume in 1914. A revised edition in two volumes, of which volume one is shown, was issued in 1935. From the Iowa Authors Collection. 


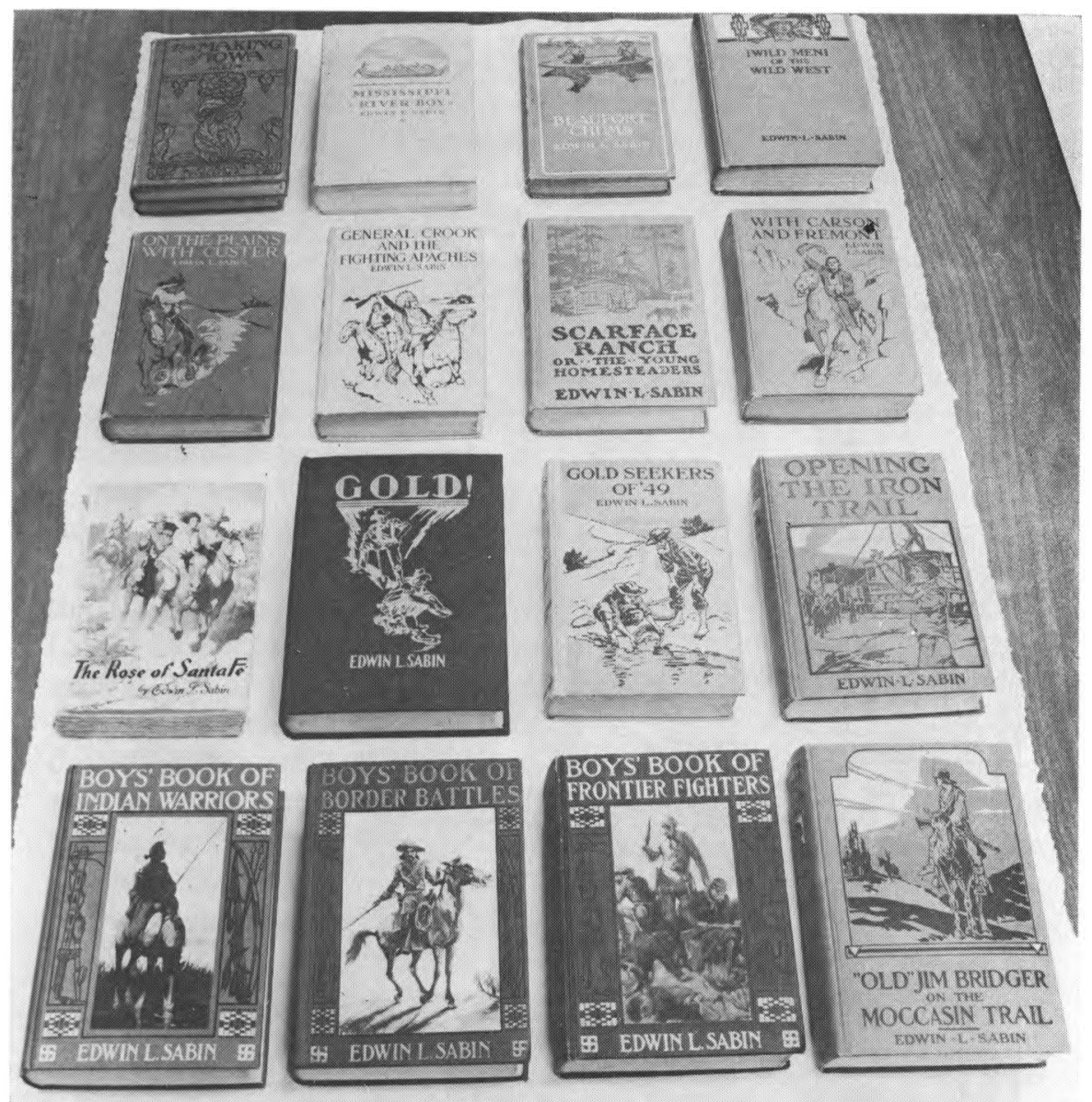

A selection of books by Iowa author Edwin L. Sabin. The Making of Iowa, shown at upper left, was co-authored by Edwin Sabin and his father, Henry Sabin, who served as Superintendent of Public Instruction for the state of Iowa from 1888 to 1892 and 1894 to 1898 . 